\title{
Two new species of the tribe Ballini Banks, 1892 from India (Araneae: Salticidae)
}

\author{
Ава новых вида трибы Ballini Banks, 1892 из Индии \\ (Araneae: Salticidae)
}

\author{
Jobi J. Malamel ${ }^{1,2}$, Dhruv A. Prajapati ${ }^{1,2,3, *}$, \\ Ambalaparambil V. Sudhikumar ${ }^{1,4}$, Pothalil A. Sebastian ${ }^{2}$ \\ Алкоби Аж. Макаме ${ }^{1,2}$, Ахрув А. Праджапати ${ }^{1,2,3, *}$, \\ Амбалапарамбия В. Судхикумар ${ }^{1,4}$, Потхалия А. Себастиан ${ }^{2}$
}

\footnotetext{
${ }^{1}$ Research and Development Centre, Bharathiar University, Coimbatore - 641 014, India.

${ }^{2}$ Division of Arachnology, Zoology Dep., Sacred Heart College, Thevara, Cochin, Kerala 682 013, India

${ }^{3}$ GEER Foundation, Indroda Nature Park, Gandhinagar, Gujarat 382007, India.

${ }^{4}$ Centre for Animal Taxonomy and Ecology, Zoology Dep., Christ College, Irinjalakuda, Kerala, 680 125, India

*Corresponding author. E-mail: dhruvspidy215@gmail.com
}

KEY WORDS. Aranei, jumping spiders, taxonomy, diagnostic characters, distribution.

КЛЮЧЕВЫЕ СЛОВА. Аranei, пауки-скакунчики, таксономия, диагностические признаки, распространение.

ABSTRACT. The genus Indomarengo Benjamin, 2004 is reported from India for the first time. Two new species of the genera Indomarengo and Marengo Peckham et Peckham, 1892 are described. Detailed morphological descriptions, diagnoses and illustrations for both species and SEM images for the new Indomarengo species are provided. Several new morphological characters of the genus Indomarengo are discussed. Collecting localities of both new species are mapped.

How to cite this article: Malamel J.J., Prajapati D.A., Sudhikumar A.V., Sebastian P.A. 2019. Two new species of the tribe Ballini Banks, 1892 from India (Araneae: Salticidae) // Arthropoda Selecta. Vol.28. No.3. P.424-434. doi: 10.15298/arthsel. 28.3.07

РЕЗЮМЕ. Род Indomarengo Benjamin, 2004 впервые отмечен из Индии. Описаны два новых вида из родов Indomarengo и Marengo Peckham et Peckham, 1892. Даны детальные морфологические описания, диагнозы и рисунки для обоих видов и SEM изображения для вида Indomarengo. Обсуждаются несколько новых морфологических признаков для рода Indomarengo. Точки находок обоих видов прокартированы.

\section{Introduction}

According to Maddison [2015], the jumping spider family Salticidae consists of 588 genera in seven subfamilies, 30 tribes and 13 subtribes. The subfamily Marpissoida Maddison et Hedin, 2003 includes three tribes: Ballini Banks, 1892, Tisanibini Maddison, 2015 and Dendryphantini Menge, 1879 [Maddison, 2015].
Jumping spiders of the tribe Ballini are distributed in Asia, Africa, Europe and Australia, accounting for 84 species in 15 genera [Maddison, 2015; WSC, 2019], but two more genera - Ligdus Thorell, 1895 and Homalattus White, 1841, which are currently listed as incertae sedis - could also be members of the Ballini [Maddison, 2015]. Asia seems to be the most diverse continent for the Ballini, whereas Europe (one genus) and Australia (two genera) are least diverse [WSC, 2019].

Based on morphological characters, Benjamin [2004, 2006] revised the Ballini and erected two Asian genera (Indomarengo Benjamin, 2004 and Leikung Benjamin, 2004) and an African one (Afromarengo Benjamin, 2004). Indomarengo consists of three species: I. chandra Benjamin, 2004, I. sarawakensis Benjamin, 2004 and I. thomsoni (Wanless, 1978) distributed in SE Asia [WSC, 2019]. In the present paper we aim (1) to describe a new Indomarengo species from India, hence recording the genus from India for the first time, and (2) to describe a new Marengo species from India. A distribution map for both species is also provided.

\section{Materials and Methods}

Fresh material was hand-collected from foliage. Specimens were studied under a LEICA S8AP0 stereomicroscope. All measurements are in $\mathrm{mm}$ and were made with the aid of ocular micrometer. Measurements of carapace and abdomen length and height were taken at the middle part of each body part. Lengths of palp and leg segments are given as follows: total (femur, patella, tibia, metatarsus (except palp), tarsus). Spine positions are as follows: prolateral, 

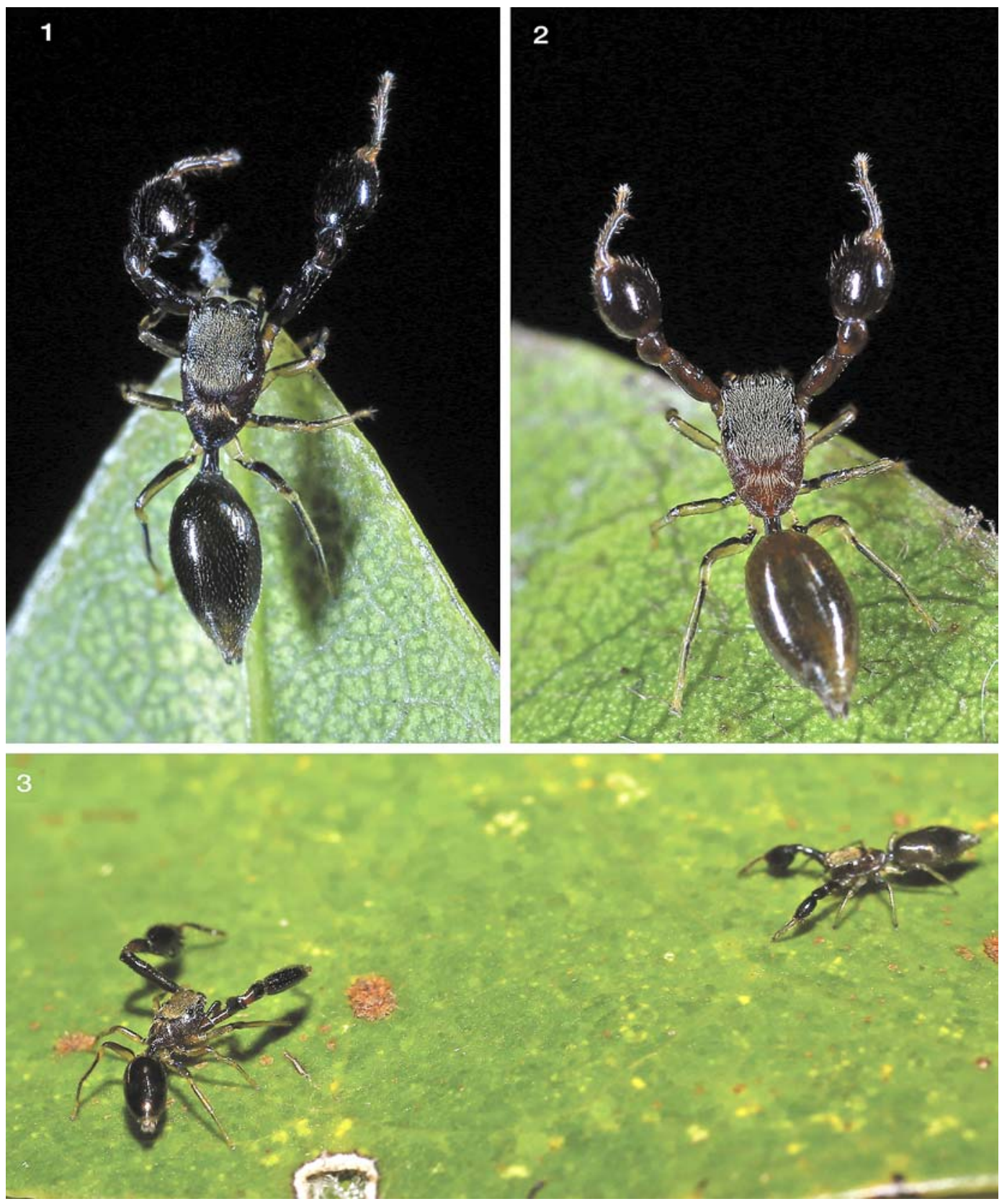

Figs 1-3. Live specimens of Indomarengo chavarapater sp.n. from Pathiramanal Island (Alappuzha, Kerala, India): 1 - male; 2 female; 3 - male (on the left) and female (on the right). Credit: Jimmy Paul.

Рис. 1-3. Живые экземпляры Indomarengo chavarapater sp.n. с острова Патираманал (Алапужа, Керала, Индия): 1 - самец; 2 самка; 3 - самец (слева) и самка (справа). Благодарность: Джим Пол.

dorsal, retrolateral and ventral. Terminology follows the format by Benjamin [2004]. Drawings were made by means of a drawing apparatus attached to the microscope. The digital images were taken by a Leica DFC2900 digital camera attached to a Leica M205A stereomicroscope with the software package Leica Application Suite (LAS), version 4.5.0. Scanning electron microscope (SEM) images were taken by means of JEOL JSM - 6390LV. The studied specimens are deposited in the reference collection at the Division of Arachnology, Zoology Department, Sacred Heart College, Thevara, Cochin, Kerala, India (ADSH).
Abbreviations used in the text: ALE - anterior lateral eye, AME - anterior median eye, PLE — posterior lateral eye, PME - posterior median eye, I-IV - 1st to 4th leg.

\section{Taxonomy}

Indomarengo Benjamin, 2004

TYPE SPECIES: I. Sarawakensis Benjamin, 2004; by the original designation. 

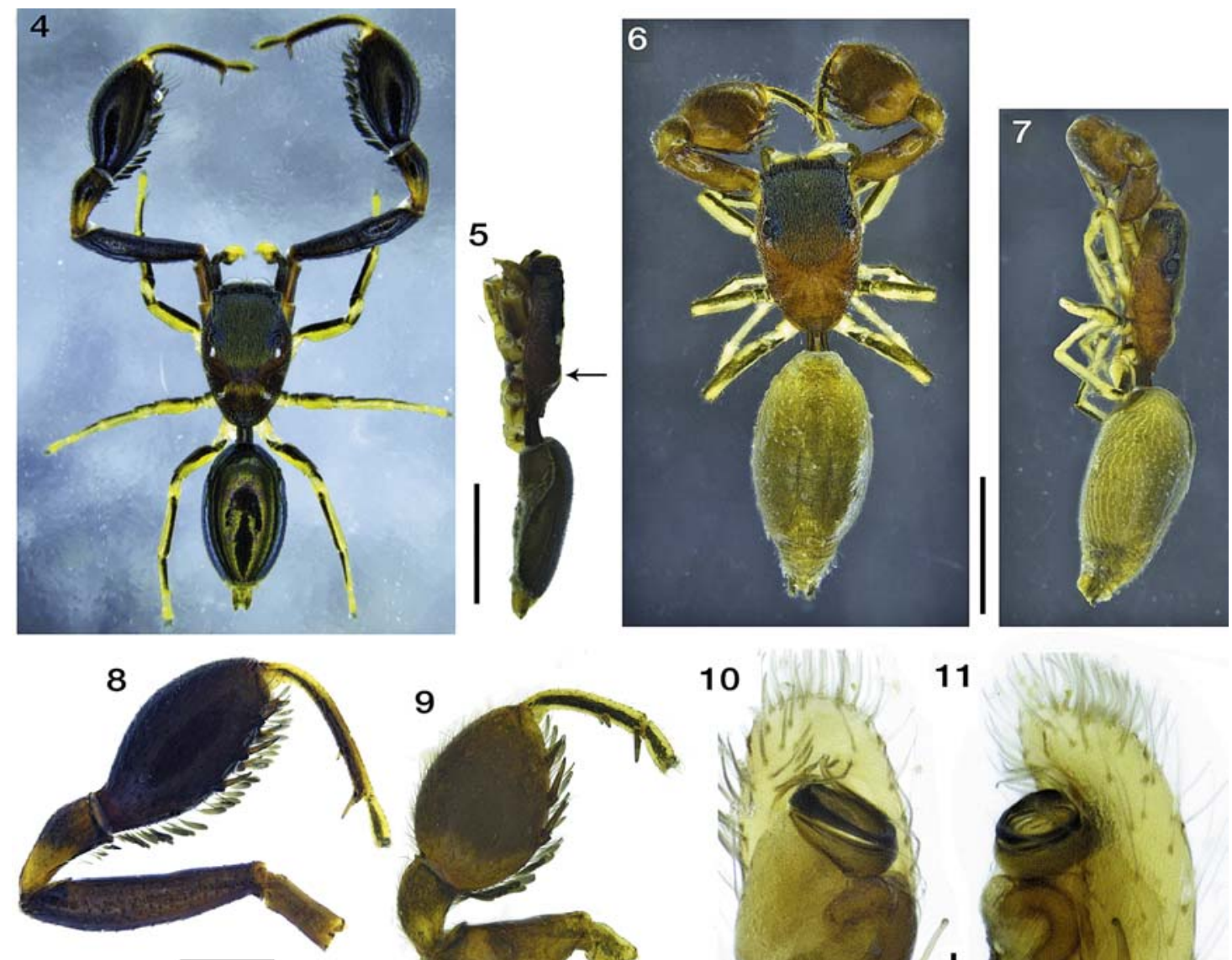

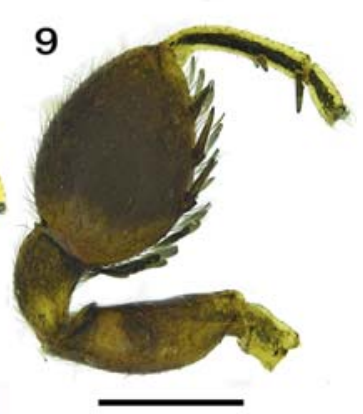

10

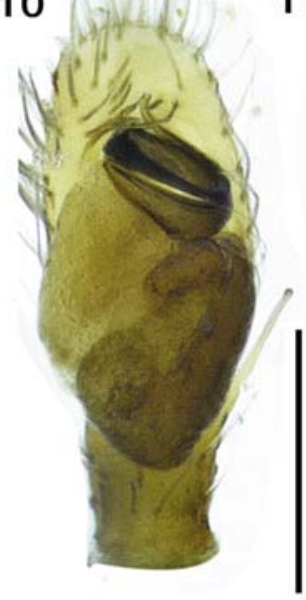

11

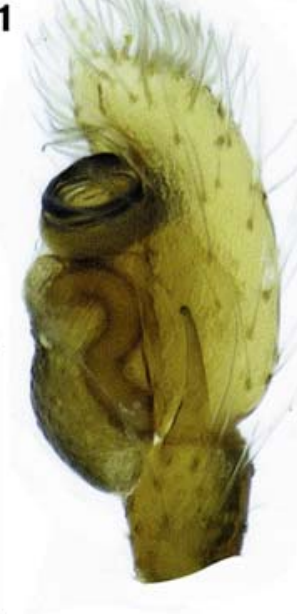

12

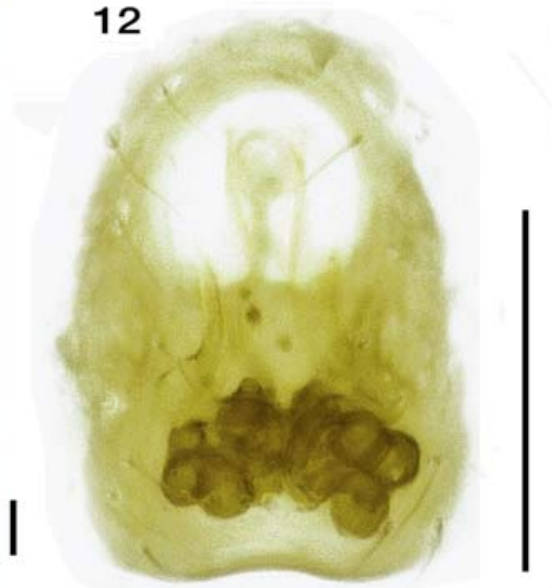

13

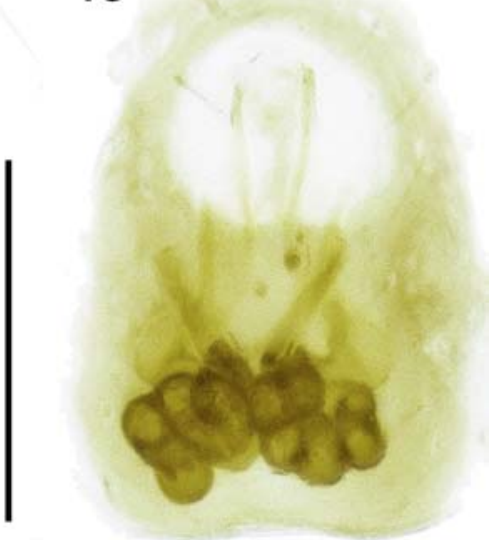

Figs 4-14. Indomarengo chavarapater sp.n., holotype male $(4,5,8,10,11)$ and paratype female $(6,7,9,12-14): 4,6-$ body, dorsal view; 5, 7 - ditto, lateral view (carapace protuberance is arrowed); 8,9 - left leg I, prolateral view; 10 - left palp, ventral view; 11 ditto, retrolateral view; 12 - epigyne, ventral view; 13 - vulva, dorsal view; 14 - epigyne, lateral view (epigynal tooth is arrowed). Scale bars: $1 \mathrm{~mm}(4-7) ; 0.5 \mathrm{~mm}(8,9) ; 0.2 \mathrm{~mm}(10-14)$.

Рис. 4-14. Indomarengo chavarapater sp.n., голотип-самец $(4,5,8,10,11)$ и паратип-самка $(6,7,9,12-14): 4,6$ - тело, вид сверху; 5, 7 - тоже, вид сбоку (выступ карапакса помечен стрелкой); 8, 9 - левая нога I, вид спереди-сбоку; 10 - левая пальпа, вид снизу; 11 - тоже, вид сбоку-сзади; 12 - эпигина, вид снизу; 13 - вульва, вид сверху; 14 - эпигина, вид сбоку (эпигинальный зубец помечен стрелкой). Масштаб: 1 мм (4-7); 0,5 мм (8, 9); 0,2 мм (10-14). 

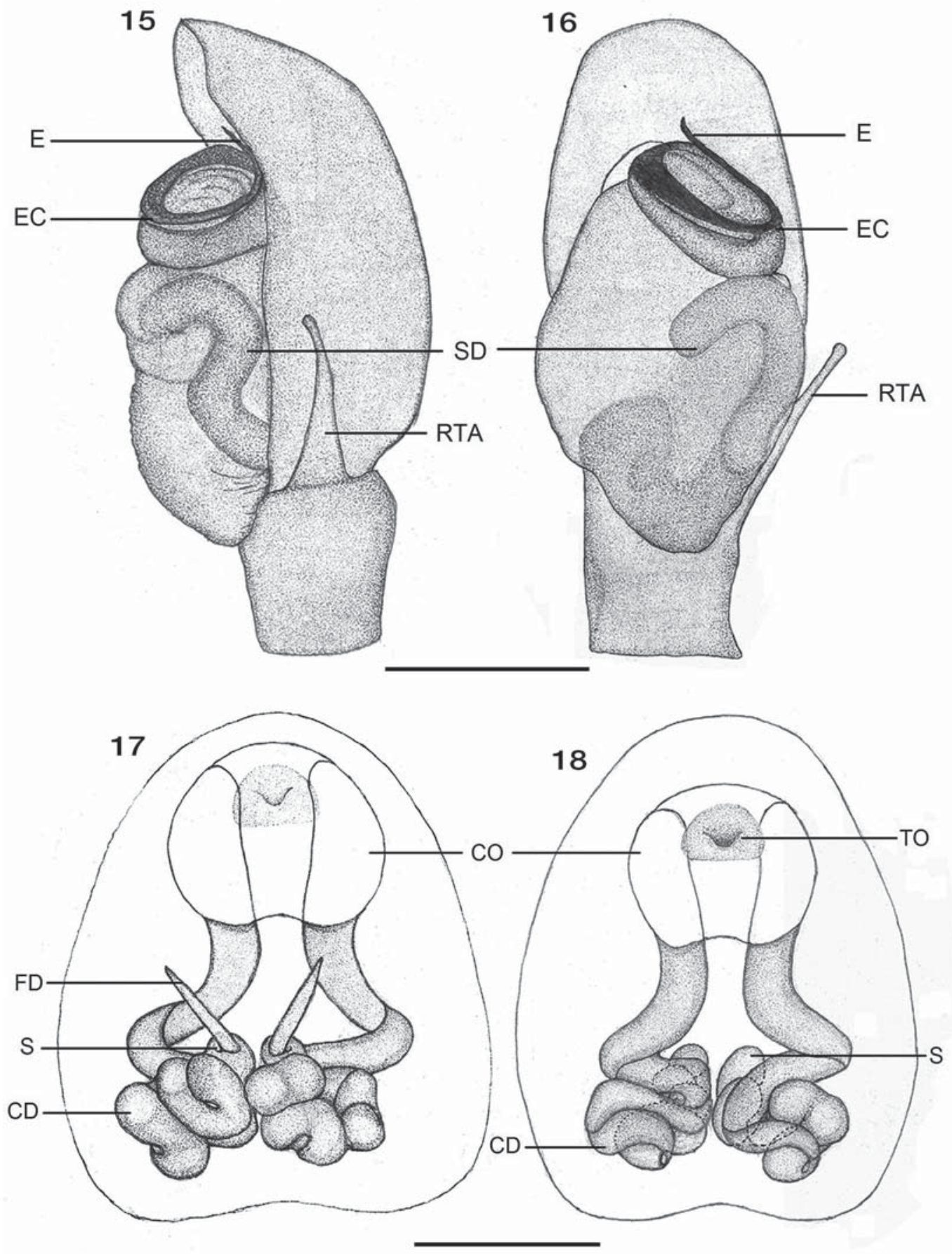

Figs 15-18. Indomarengo chavarapater sp.n., holotype male $(15,16)$ and paratype female $(17,18): 15$ - left palp, retrolateral view; 16 - ditto, ventral view; 17 - vulva, dorsal view; 18 - epigyne, ventral view.

Abbreviations: $\mathrm{CD}$ - insemination duct, $\mathrm{CO}$ - copulatory opening, E — embolus, EC — embolic coil, FD — fertilization duct, RTA retrolateral tibial apophysis, S - spermatheca, SD - sperm duct, TO - epigynal tooth. Scale bars: $0.1 \mathrm{~mm}$.

Рис. $15-18$. Indomarengo chavarapater sp.n., голотип-самец $(15,16)$ и паратип-самка $(17,18): 15$ - левая пальпа, вид сбокусзади; 16 - тоже, вид снизу; 17 - вульва, вид сверху; 18 - эпигина, вид сверху.

Сокращения: $\mathrm{CD}$ - осеменительный каналец, $\mathrm{CO}$ - копулятивное отверстие, E - эмболюс, EC — завито эмболюса, FD оплодотворительный каналец, RTA - заднебоковой отросток голени, S - сперматека, SD — семенной каналец, TO — эпигинальный зубец. Масштаб: 0,1 мм. 

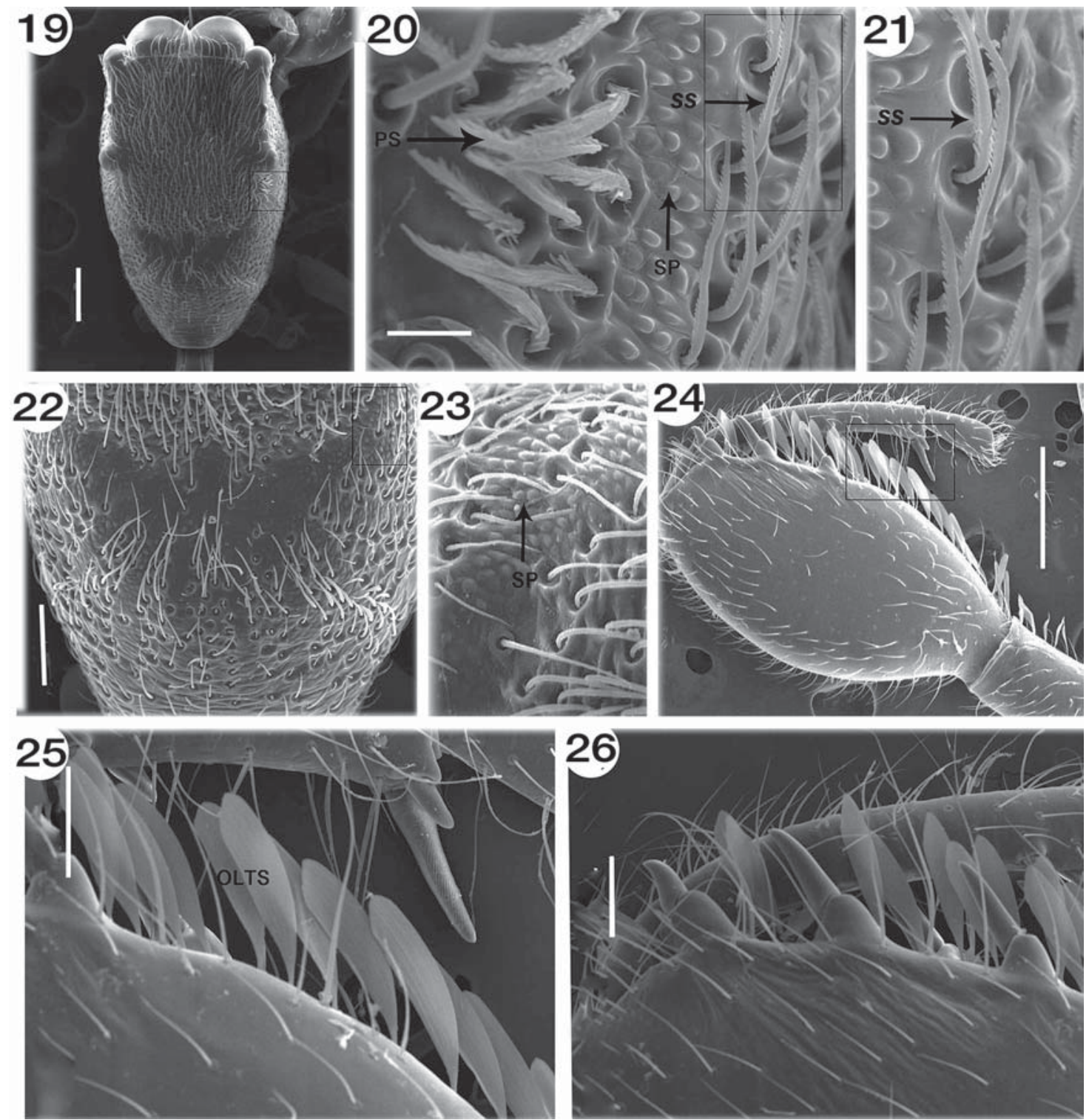

Figs 19-26. Indomarengo chavarapater sp.n., paratype female: 19 - carapace, dorsal view; 20, 21 - enlarged portion of carapace (outlined in figs 19 and 20); 22 - thorax, dorsal view; 23 — enlarged portion of thorax (outlined in fig. 22) showing scattered papillae; 24 left leg I showing spine position and leaf-like scales on ventral side of tibia and patella (few); 25 — leaf-like scales on tibia I; 26 position of spine on tibia I.

Abbreviations: OLTS - leaf-like scales, PS - plumose setae, SP — scattered papillae, SS - serrated setae. Scale bars: $0.2 \mathrm{~mm}(19$, 29), $0.02 \mathrm{~mm}(20), 0.1 \mathrm{~mm}(22,25,26), 0.5 \mathrm{~mm}(25)$.

Рис. 19-26. Indomarengo chavarapater sp.n., паратип-самка: 19 - головогрудь, вид сверху; 20, 21 - увеличенная секция головогруди (очерчена на рис. 19 и 20); 22 - грудной отдел, вид сверху; 23 - увеличенная секция грудного отдела (очерчена на рис. 22), показаны разбросанные папиллы; 24 - лева нога I, показано положение шипа и листьеобразных чешуек на вентральной стороне голени и колена (немного); 25 - листьеобразные чешуйки на голени I; 26 — положение шипа на голени I.

Сокращения: OLTS - листьеобразные чешуйки, PS - перистые шетинки, SP - разбросанные папиллы, SS - зазубренные щетинки. Масштаб: 0,2 мм (19, 29), 0,02 мм (20), 0,1 мм (22, 25, 26), 0,5 мм (25), 0,2 мм (29).

COMMENTS: For description and diagnosis of the genus, see Benjamin [2004].

\section{Indomarengo chavarapater sp.n. \\ Figs 1-26, Map.}

TYPES: Holotype $O^{7}$ (ADSH842231A) from India, Kerala, Alappuzha, Pathiramanal Island $\left(9^{\circ} 37^{\prime} 07.11^{\prime \prime} \mathrm{N}, 76^{\circ} 23^{\prime} 04.95^{\prime \prime} \mathrm{E}\right)$, c.
$4 \mathrm{~m}$ a.s.l., hand-collected from foliage, 14.02.2015, M.J. Jobi, M.S. Pradeep \& J. Paul. - Paratypes: 3 우 (ADSH842231B), same locality as that of the holotype, 19.11.2015 \& 22.05.2016, M.J. Jobi, M.S. Pradeep \& J. Paul.

ETYMOLOGY. This species name is a noun in apposition and dedicated to Saint Chavara who was a great educator and founder of the Carmelites of Mary Immaculate (CMI) congregation, the first Catholic congregation in India. The 


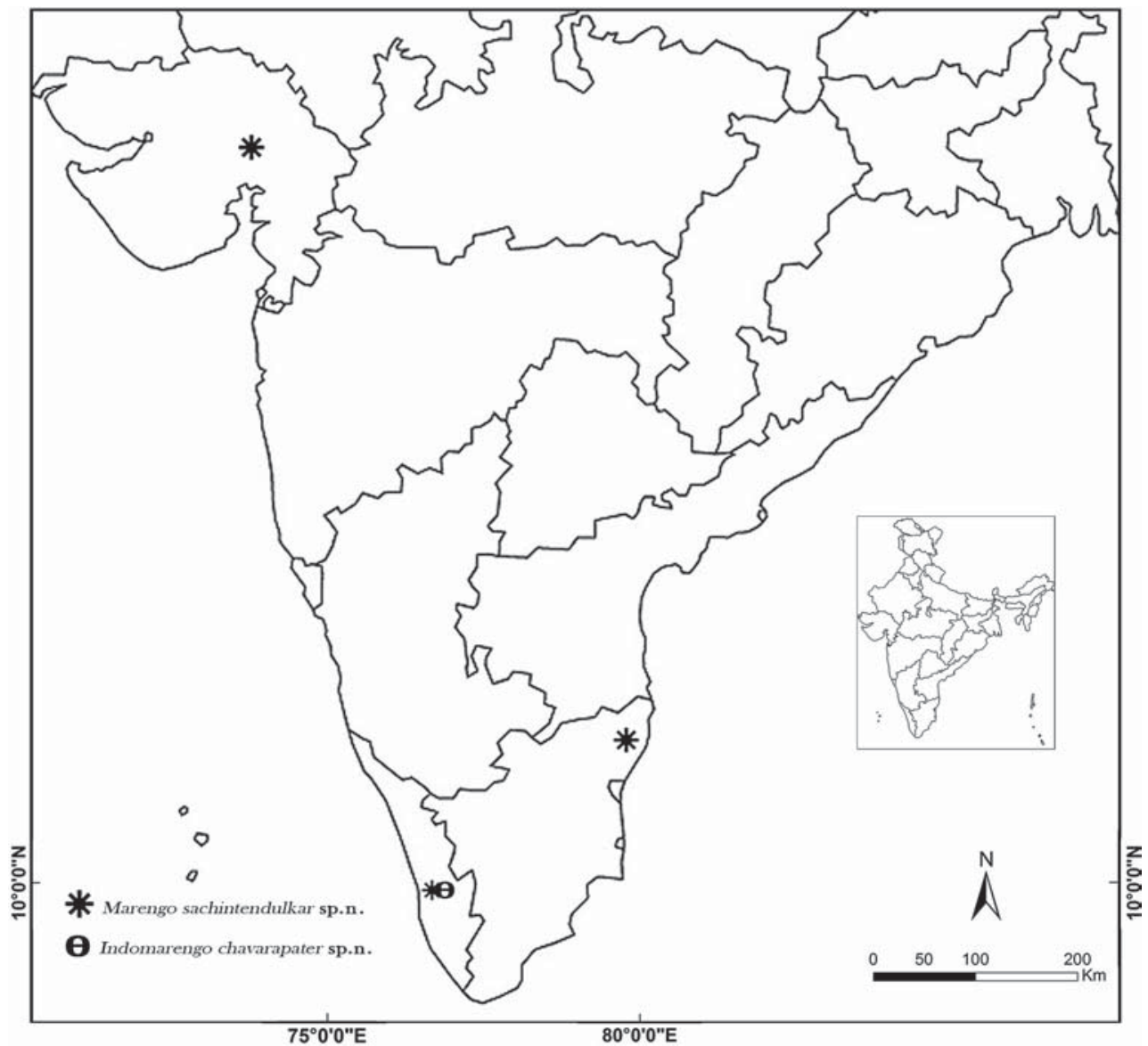

Map. Collecting localities of Indomarengo chavarapater sp.n. and Marengo sachintendulkar sp.n. in India.

Карта. Точки находок Indomarengo chavarapater sp.n. и Marengo sachintendulkar sp.n. в Индии.

affiliated institution of all the authors is run by the CMI congregation.

DIAGNOSIS. The new species can easily be distinguished from all the Indomarengo species by the shape of embolus and retrolateral tibial apophysis (Figs 10, 11, 15, 16), the presence of leaf-like scales on the ventral side of tibia I (Figs 8, 9, 24, 25: OLTS), and the conformation of the epigyne (Figs 12-14, 17, 18).

DISTRIBUTION. The type locality only (Map).

DESCRIPTION. Male (holotype; Figs 1, 3-5, 8). Measurements. Body length 3.12. Carapace length 1.54, width (at the middle) 0.90, height (at the middle) 0.36. Abdomen length 1.58 , width (at the middle) 0.88 , height (at the middle) 0.47. Eye diameter: ALE 0.11. AME 0.27. PLE 0.10. PME 0.04. Eye interdistances: AME-AME 0.006. AMEALE 0.005. ALE-ALE 0.49. ALE-PME 0.21. PLE-PLE 0.61. PME-PME 0.63. PME-PLE 0.15. Clypeus height at ALE 0.15, at AME 0.014. Chelicera length 0.22. Length of palp and leg segments. Palp 0.86 [0.31, 0.12, 0.10, 0.33], I $4.08[1.30,0.50,1.15,0.88,0.25]$, II 1.91 [0.59, 0.22, 0.47, $0.44,0.19]$, III $1.69[0.49,0.17,0.40,0.42,0.21]$, IV 2.13 $[0.64,0.21,0.61,0.48,0.23]$. Leg formula: 1423 . Leg/palp spination. Palp 0100, 0000, 0000, 0000; femora I-IV 0000; patellae I-IV 0000; tibia 0006, tibiae II-IV 0000; metatarsus I 0004, metatarsi II-IV 0000; tarsi I-IV 0000. Coloration. Carapace oval, with little protuberance on its posterior part (arrowed in Fig. 5); cephalic region blackish, with yellowish shiny setae; other parts of carapace reddish brown, with numerous pits containing setae (Figs 4, 22); small bunch of white plumose scales behind PLEs making a small white dot and similar scales on postero-lateral sides of thoracic region making a small transverse band (Figs 1,4); distinctive single side serrated scales on lateral sides of PLEs (Figs 20,21); black around eyes; there are numerous small scattered papillae on lateral and posterior sides of PLEs (Figs 20, 23). Clypeus, sternum, labium, endites and chelicerae yellowish brown, without any marking. Chelicerae with two promarginal and three retromarginal teeth; light yellow fang short. Legs I-IV laterally with dark markings; leg I with enlarged femur and tibia; six spines $(0 / 2 / 2 / 2$; spination style as in Benjamin [2004]) on ventral side of tibia I with leaf-like scales (OLTS) and few long thread like setae (Figs 8, 24-25), some leaf-like scales present on antero-ventral side of patella I, metatarsus I with four ventral spines $(2 / 2$; spination style as in Benjamin [2004]), prolatero-ventral spine of the first pair is largest (Figs 8, 24-26). Abdomen oval, dorsally shiny dark brownish, ventrally yellowish brown, without any pattern and with a dorsal scutum. Spinnerets yellowish brown (Figs 1, 4, 5). Palp as in Figs 10, 11, 15, 16: palpal segments dark brown except for light brown cymbium, femur dorsally with a single apical spine, retrolateral tibial apophysis long and slightly bent at its end, 
tapering to pointed tip, directed at near to one o'clock position (in ventral view) (Figs 10, 11, 15, 16); cymbium oval, longer than wide; tegulum brownish, bilobed, projecting outwards; a 'question mark'-shaped orientation of sperm duct can be seen in lateral view (Figs 11, 15); embolus thin, long and whip-like, its tip directed at 12 o'clock position (in ventral view), coils more than 1.5 times (Figs 10, 16).

Female (paratype, Figs 2, 3, 6-7, 9). Measurements. Body length 3.11. Carapace length 1.23, width (at the middle) 0.73 , height (at the middle) 0.40 . Abdomen length 1.88 , width (at the middle) 0.88 , height (at the middle) 0.73 . Eye diameter: ALE 0.09. AME 0.24. PLE 0.10. PME 0.04. Eye interdistances: AME-AME 0.005. AME-ALE 0.006. ALEALE 0.44. ALE-PME 0.14. PLE-PLE 0.55. PME-PME 0.51. PME-PLE 0.13. Clypeus height at ALE 0.14, at AME 0.01 . Chelicera length 0.16 . Length of palp and leg segments. Palp 0.67 [0.26, 0.10, 0.13, 0.18], I 2.33 [0.63, 0.29, $0.72,0.53,0.16]$, II $1.45[0.43,0.20,0.35,0.29,0.18]$, III $1.35[0.41,0.16,0.31,0.29,0.18]$, IV $1.77[0.56,0.18$, $0.50,0.33,0.20]$. Leg formula: 1423 . Leg/palp spination. Palp spineless; femora I-IV 0000; patellae I-IV 0000; tibia 0006, tibiae II-IV 0000; metatarsus I 0004, metatarsi II-IV 0000; tarsi I-IV 0000. Coloration. In all respects as the male, except as follows: thoracic region and sides of carapace dark brown; lesser (than in the male) plumose scales on postero-lateral side of carapace; patella I without leaf-like setae (Fig. 9); abdomen yellowish brown, sides with yellowish striae (Figs 6, 7), dorsal scutum restricted to the cardiac region only (Figs 6, 7). Epigyne and vulva as in Figs 12-14, 17, 18: epigyne with a prominent tooth on its apical margin (Figs 14 arrowed, 17, 18); without a gland of copulatory atrium (Figs 12-14, 17, 18); two copulatory openings and long epigynal atria are separated by a narrow septum (Figs $12,13,17,18)$; vulva without a thin, translucent septum (Figs 13, 17); insemination ducts long and complex (Figs $12,13,17,18)$; spermathecae small and nearly circular in shape with erected fertilization ducts (Figs 13, 17).

REMARKS. I. chavarapater sp.n. possesses several characters that are unknown in other Indomarengo species, viz.:
(1) the presence of a tooth in between copulatory openings and close to the upper epigynal margin in the females instead of just the apical margin, as in Leikung (Figs 14 arrowed, 17, 18); (2) the presence of serrated scales on lateral sides of the carapace below PLEs (Figs 20-21); (3) the presence of leaf-like scales on the ventral side of tibia I, as in Philates chelifer (Simon, 2004) and Afromarengo species (Figs 8-9, 24-25, OLTS); (4) 'question mark'-shaped orientation of the sperm duct in male palps, as seen in retrolateral view (Figs 10, 11, 15, 16) (nearly ' $Z$-shaped' in other Indomarengo species; cf. figs 38E, 41E, 42B in Benjamin [2004]). Such a unique combination of the characters could mean that the described species may even be considered in a genus of its own.

\section{Marengo Peckham et Peckham, 1892}

TYPE SPECIES: Marengo crassipes Peckham et Peckham, 1892; by the original designation.

COMMENTS: For diagnostic features of the genus, see Benjamin [2004].

\section{Marengo sachintendulkar sp.n.} Figs 27-49, Map.

TYPES: HoLOTYPE $\mathrm{O}^{7}$ (ADSH 843015A) from India, Gujarat, Gujarat University campus in Ahmadabad $\left(23^{\circ} 02^{\prime} 15.66^{\prime \prime} \mathrm{N}, 72^{\circ} 32^{\prime}\right.$ 35.24"E), $53 \mathrm{~m}$ a.s.1., hand-collected from foliage, 15.02.2014, D.A. Prajapati. - PARATYPES: INDIA: $1 \sigma^{7}, 1$ क (ADSH 843015B), Tamil Nadu, Vedanthagal bird sanctuary in Kancheepuram $\left(12^{\circ}\right.$ $\left.32^{\prime} 44^{\prime \prime} \mathrm{N}, 79^{\circ} 51^{\prime} 21^{\prime \prime} \mathrm{E}\right), 122 \mathrm{~m}$ a.s.l., hand-collected from foliage, 22.07.2016, K.S. Nafin \& A. Pooja; 1 + (ADSH 843015C), Kerala, Alappuzha Pathiramanal Island $\left(9^{\circ} 37^{\prime} 07.11^{\prime \prime} \mathrm{N}, 76^{\circ} 23^{\prime} 04.95^{\prime \prime} \mathrm{E}\right), 4$ $\mathrm{m}$ a.s.l., hand-collected from foliage, 14.11.2015, M.J. Jobi, M.S. Pradeep \& P. Jimmy,

ETYMOLOGY. The new species is dedicated to the Indian cricketer Bharat Ratna Sachin Tendulkar, also known as the 'God of Cricket' and 'Master Blaster', for his extraordinary and unbreakable records in the game of cricket; the species name is a noun in apposition.

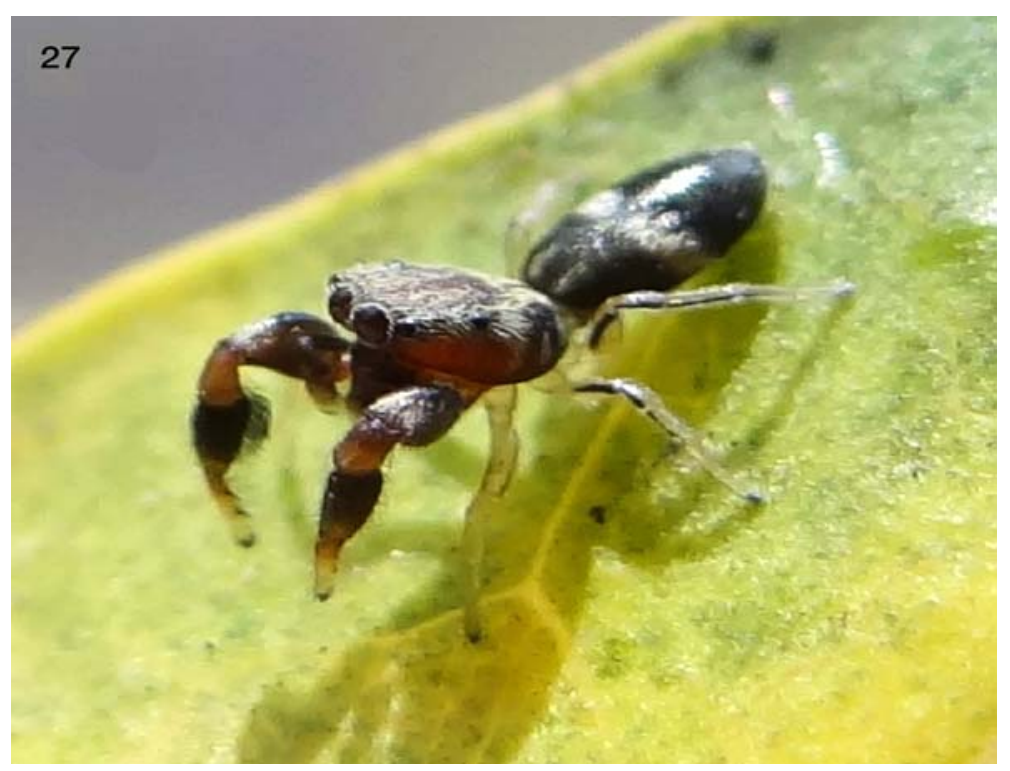

Fig. 27. Live holotype male of Marengo sachintendulkar sp.n. Credit: Dhruv Prajapati.

Рис. 27. Живой самец-голотип Marengo sachintendulkar sp.n. Благодарность: Дхрув Праджапати. 

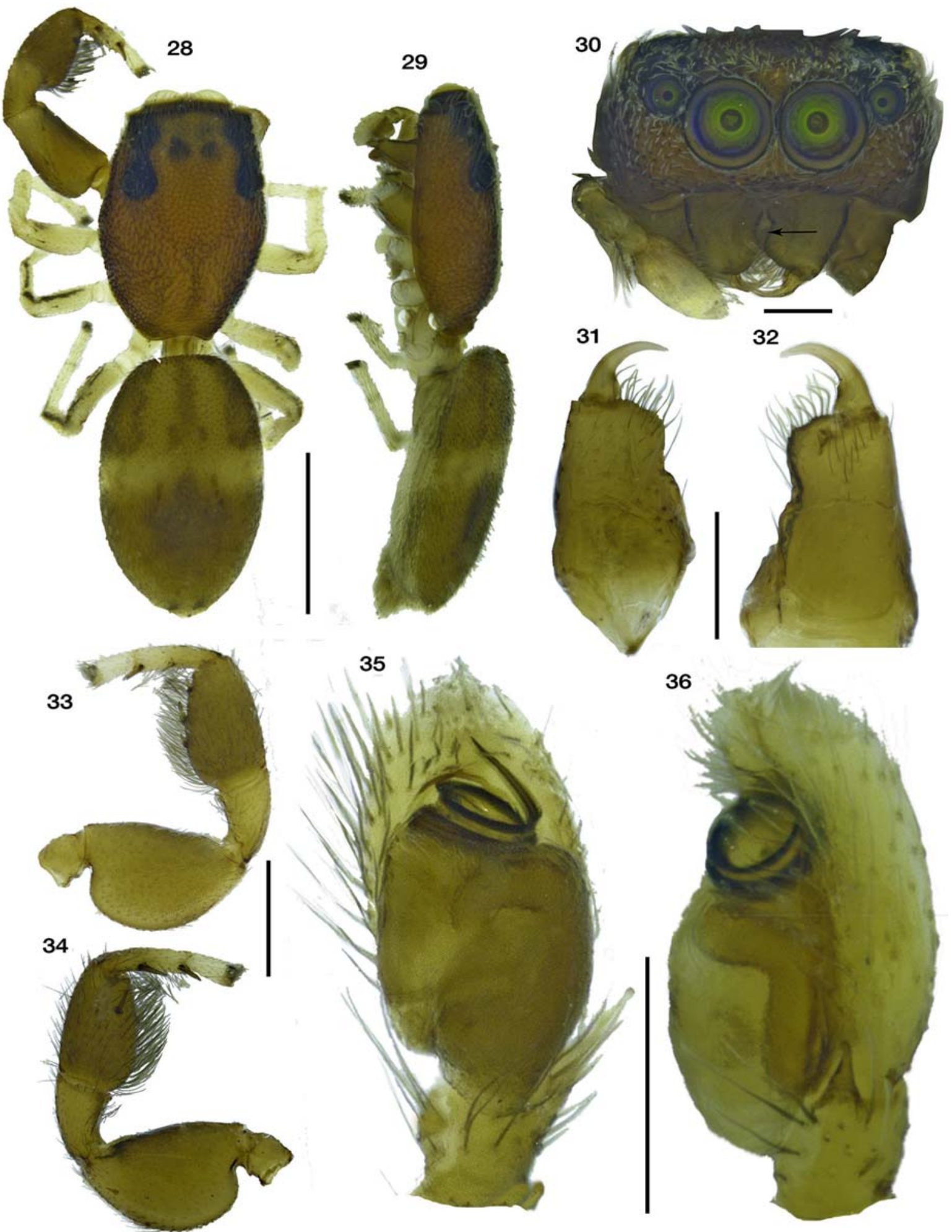

Figs 28-36. Holotype male of Marengo sachintendulkar sp.n.: 28 - body, dorsal view; 29 - ditto, lateral view; 30 - carapace, frontal view (gap between chelicerae is arrowed); 31 - chelicera, dorsal view; 32 - ditto, ventral view; 33 - left leg I, retrolateral view; 34 - ditto, prolateral view; 35 - left palp, ventral view; 36 - ditto, retrolateral view. Scale bars: $1 \mathrm{~mm}(28,29) ; 0.2 \mathrm{~mm}(30-32,35,36)$; $0.5 \mathrm{~mm}(33,34)$.

Рис. 28-36. Самец-голотип Marengo sachintendulkar sp.n.: 28 - тело, вид сверху; 29 - тоже, вид сбоку; 30 - головогрудь, вид спереди (промежуток между хелицерами показан стрелкой); 31 - хелицера, вид сверху; 32 - тоже, вид снизу; 33 - левая нога I, вид сзади-сбоку; 34 - тоже, вид спереди-сбоку; 35 - левая пальпа, вид снизу; 36 - тоже, вид сзади-сбоку. Масштаб: 1 мм $(28,29) ; 0,2$ мм $(30-32,35,36) ; 0,5$ мм $(33,34)$. 

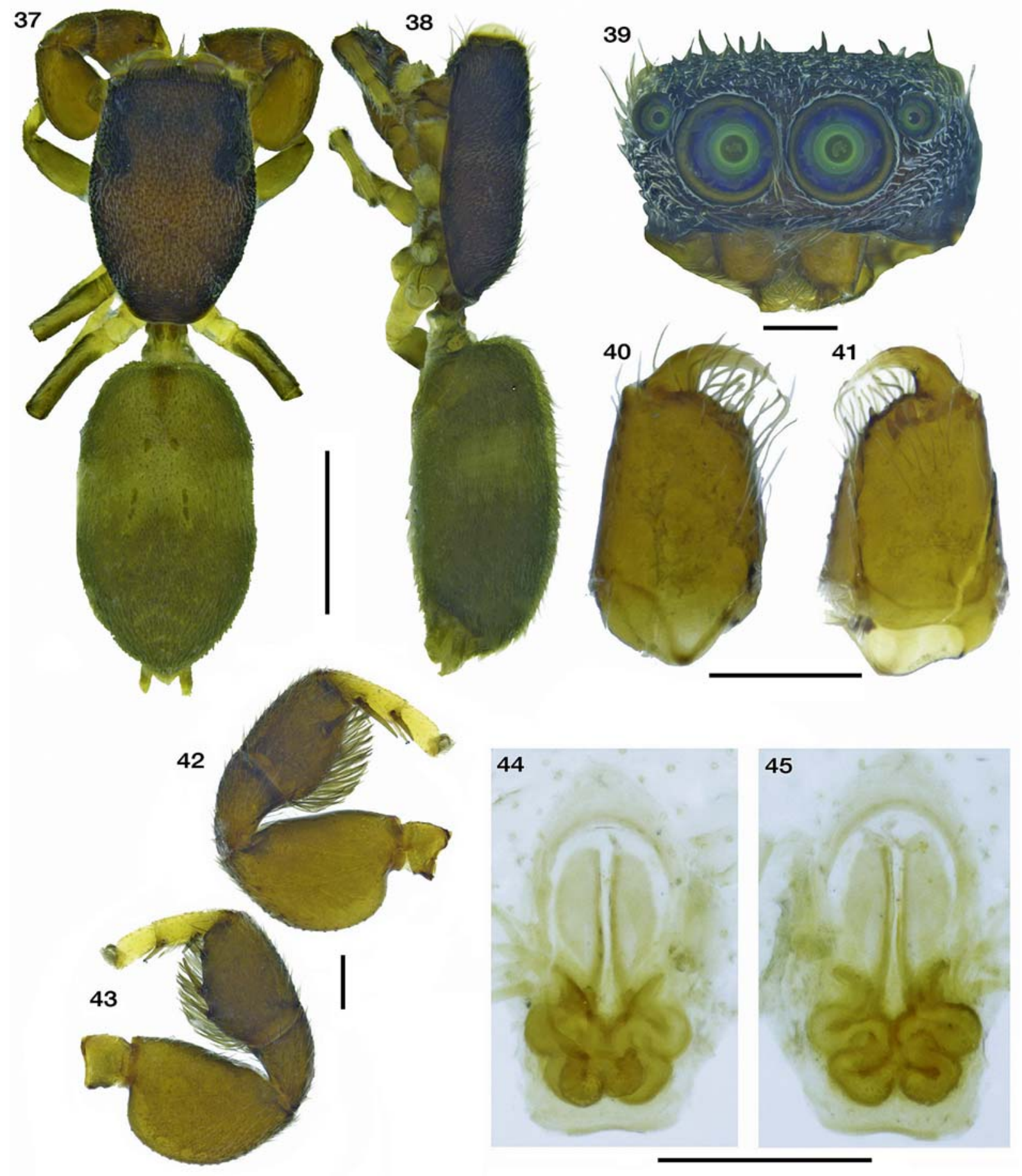

Figs 37-45. Marengo sachintendulkar sp.n., paratype female from Vedanthagal bird sanctuary, (Kancheepuram, Tamil Nadu, India): 37 - body, dorsal view; 38 - ditto, lateral view; 39 - carapace, frontal view; 40 - chelicera, dorsal view; 41 - ditto, ventral view; 42 left leg I, prolateral view; 43 — ditto, retrolateral view; 44 - epigyne, ventral view; 45 — vulva, dorsal view. Scale bars: 1 mm (37, 38); $0.2 \mathrm{~mm}(39-45)$

Рис. 37-45. Marengo sachintendulkar sp.n., самка-паратип из птичьего заповедника Ведантхагал (Канчипурам, Тамил Над, Индия): 37 - тело, вид сверху; 38 - тоже, вид сбоку; 39 - головогрудь, вид спереди; 40 - хелицера, вид сверху; 41 - тоже, вид снизу; 42 - левая нога I, вид спереди-сбоку; 43 — тоже, вид сзади-сбоку; 44 — эпигина, вид снизу; 45 — вульва, вид сверху. Масштаб: 1 мм $(37,38) ; 0,2$ мм (39-45). 

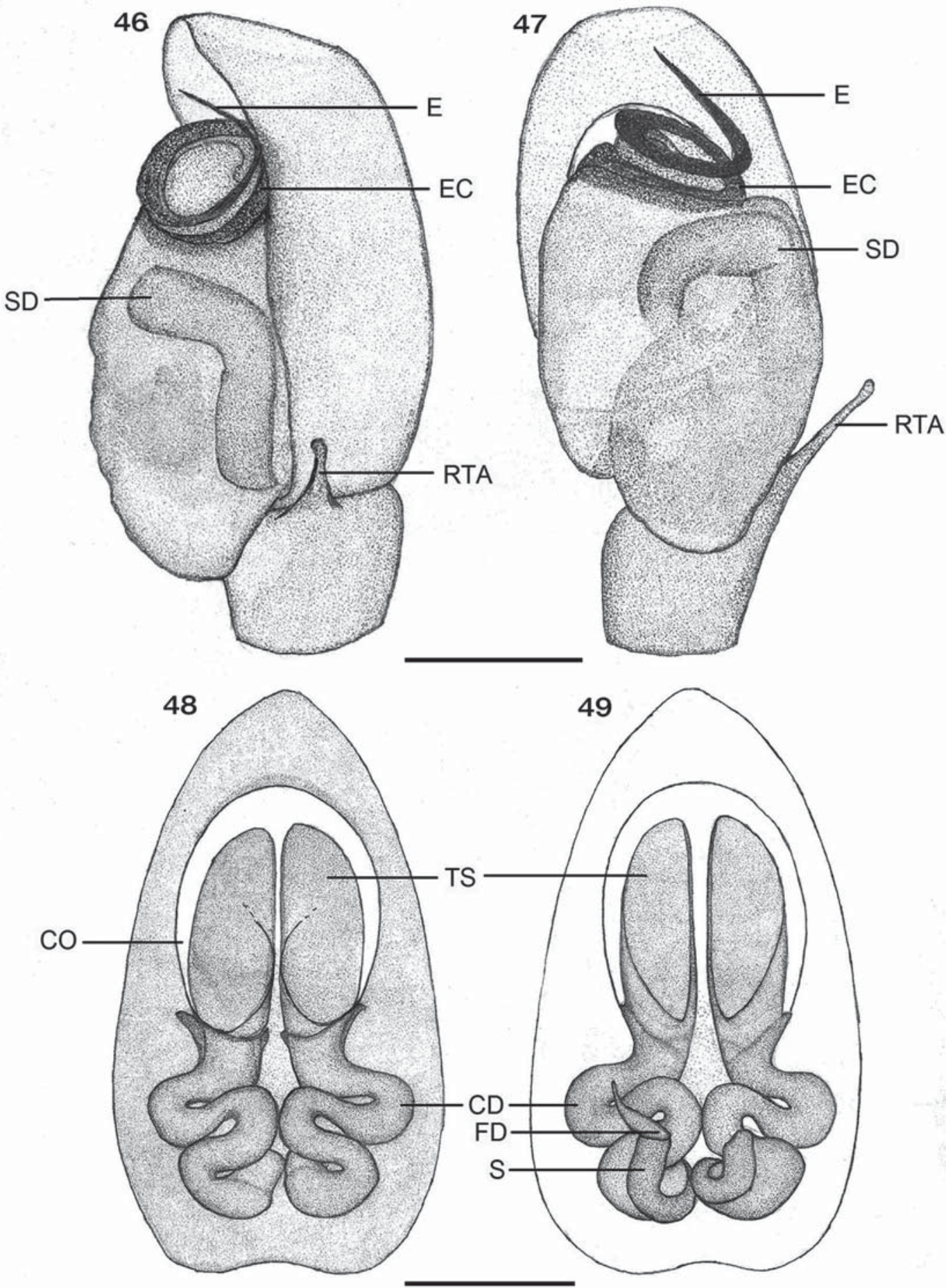

Figs 46-49. Marengo sachintendulkar sp.n., holotype male $(46,47)$ and paratype female $(48,49)$ : 46 — left palp, retrolateral view; 47 - ditto, ventral view; 48 - epigyne, ventral view; 49 - vulva, dorsal view.

Abbreviations: $\mathrm{CD}$ - insemination duct, $\mathrm{CO}$ - copulatory opening, E — embolus, EC — embolic coil, FD — fertilization duct, RTA retrolateral tibial apophysis, $\mathrm{S}$ - spermatheca, SD — sperm duct, TS - translucent septum. Scale bars: $0.1 \mathrm{~mm}$.

Рис. 46-49. Marengo sachintendulkar sp.n., самец-голотип $(46,47)$ и паратип-самка $(48,49)$ : 46 - левая пальпа, вид сбокусзади; 47 - тоже, вид снизу; 48 - эпигина, вид снизу; 49 - вульва, вид сверху.

Сокращения: $\mathrm{CD}$ - осеменительный каналец, $\mathrm{CO}$ - копулятивное отверстие, E — эмболюс, EC — завиток эмболюса, FD оплодотворительный каналец, RTA - задне-боковой отросток голени, S - сперматека, SD - семенной каналец, TS - прозрачный септум. Масштаб: 0,1 мм. 
DIAGNOSIS. M. sachintendulkar sp.n. is most similar to $M$. crassipes (cf. figs 60-64 in Benjamin [2004]) and $M$. nitida Simon, 1900 (cf. figs 1A-B, 1E, 2-4 in Benjamin [2004]), but can be distinguished from both by the following combination of characters: abdomen with a median discontinuous whitish transverse band and two antero-medial longitudinal stripes reaching the transverse band (Figs 28, 29, 37,38 ), only four spines on tibia I (Figs 33-34, 42-43) (six in all the Marengo species), the presence of cheliceral notch in the males that makes a significant gap in between the chelicerae (Fig. 30, arrowed), the orientation of the embolic coil (Figs 35, 36, 46, 47), the embolus narrowing at its distal end, with a sharp pointed tip, and the S-shaped insemination ducts in the females (Figs 44, 45, 48, 49).

DISTRIBUTION. North-West and South India (Map).

DESCRIPTION. Male (holotype, Figs 28, 29). Measurements. Body length 3.07. Carapace length 1.44, width (at the middle) 1.04, height (at the middle) 0.53. Abdomen length 1.63, width (at the middle) 1.02, height (at the middle) 0.61. Eye diameter: ALE 0.12. AME 0.27. PLE 0.12. PME 0.03. Eye interdistances: AME-AME 0.02. AMEALE 0.018. ALE-ALE 0.55. ALE-PME 0.13. PLE-PLE 0.76. PME-PME 0.77. PME-PLE 0.20. Clypeus height at ALE 0.22, at AME 0.05. Chelicera length 0.26. Length of palp and leg segments. Palp 0.99 [0.38, 0.22, 0.10, 0.29], I $2.04[0.64,0.32,0.56,0.34,0.18]$, II 1.49 [0.50, 0.21, 0.31, $0.29,0.18]$, III 1.36 [0.43, 0.19, 0.27, 0.28, 0.19], IV 1.74 $[0.63,0.21,0.40,0.32,0.18]$. Leg formula: 1423 . Leg/palp spination. Palp 0100, 0000, 0000, 0000; femur I 0100, femora II-IV 0200; patellae I-IV 0000; tibia I 0004, tibia II 0001, tibiae III-IV 0000; metatarsus I 0004, metatarsi II-IV 0000; tarsi I-IV 0000. Coloration. Carapace oval, reddish brown, with scattered whitish setae, without colour markings except for two black patches anteriorly, black around eyes (Figs 28, 29). Endites, labium and sternum pale yellow. Chelicerae light brown, without colour markings. Chelicerae modified, with a prominent median notch on their retrolateral side making a significant gap in between chelicerae (Fig. 30 arrowed, 31, 32); lateral margins rebordered, prolateral margin with four stout setae arranged in a single row, baso-retrolaterally five stout setae (Fig. 31); chelicerae with two minute promarginal and two retromarginal teeth (Fig. 32); light yellow fangs short (Figs 31, 32). Legs I-IV laterally with black markings; leg I darkest, femur I with a single dorsal spine, tibia I with four ventral spines $(0 / 1 / 2 / 1$; spination style as in Benjamin [2004]), one prolatero-ventral and three retrolateral-ventral, metatarsus I with four ventral spines (Figs 33, 34) (2/2; spination style as in Benjamin [2004]). Abdomen oval, with a dorsal scutum; with three pairs of sigillae; dorsum yellowish brown except the dark brown posterior part; abdomen with a median discontinuous whitish band and two antero-medial longitudinal stripes reaching the median transverse band (Fig. 28); lateral and ventral part of abdomen whitish cream-coloured, sides with blackish striae (Fig. 29). Palp as in Figs 35, 36, 46, 47: palpal segments dark brown except for light brown cymbium, femur dorsally with a single apical spine, retrolateral tibial apophysis short, slender, tapering to a pointed end, directed at near at two o'clock (in ventral view) (Figs 35, 36, 46, 47); cymbium oval, longer than wide; tegulum brownish, bilobed, projecting outwards; an 'inverted L-shaped' orientation of sperm duct can be seen in lateral view (Figs 36, 46); embolus long, second embolic coil more curved making a perfect 'V-shaped' figure with a pointed embolic tip (Figs 35, 47), embolic tip directed at 11 o'clock (in ventral view) (Figs 35, 47), coils more than 1.5 times (Figs 35, 47).
Female (paratype, Figs 37-38). Measurements. Body length 3.54. Carapace length 1.58 , width (at the middle) 1.03, height (at the middle) 0.50. Abdomen length 1.96, width (at the middle) 1.09 , height (at the middle) 0.87. Eye diameter: ALE 0.12. AME 0.29. PLE 0.12. PME 0.04. Eye interdistances: AME-AME 0.019. AME-ALE 0.017. ALEALE 0.62. ALE-PME 0.12. PLE-PLE 0.75. PME-PME 0.80. PME-PLE 0.20. Clypeus height at ALE 0.25, at AME 0.07 . Chelicera length 0.21 . Length of palp and leg segments. Palp $0.75[0.29,0.09,0.14,0.23]$, I 1.82 [0.62, 0.28, $0.49,0.25,0.18]$, II $1.47[0.47,0.23,0.31,0.24,0.22]$, III $1.43[0.48,0.18,0.25,0.29,0.23]$, IV $1.84[0.63,0.22$, $0.43,0.34,0.22]$. Leg formula: 4123 . Leg/palp spination. Palp 0000, 0000, 0000, 0000; femur I 0200, femora II-IV 0100; patellae I-IV 0000; tibia I 0004, tibia II 0001, tibiae III-IV 0000; metatarsus I 0004, metatarsi II-IV 0000; tarsi I-IV 0000. Coloration. In all respects as the male except as follows: carapace maroon-coloured, with scattered whitish setae on lateral sides of thoracic region (Figs 37-38); endites, labium, sternum and chelicerae brownish, without colour markings; chelicerae without a median notch (Figs 4041); retrolateral cheliceral margin less rebordered (Fig. 41), without stout setae; chelicerae with two minute promarginal and three retromarginal teeth (Fig. 41); fangs light yellow, short (Figs 40-41); femur I with two dorsal spines; abdomen brownish, its antero-medial region lighter, but without a longitudinal band (Fig. 37); dorsal scutum restricted to the cardiac region only (Fig. 37), sides without any striae (Fig. 38). Epigyne and vulva as in Figs 44-45, 48-49: epigyne with 'S-shaped' insemination ducts (Figs 44-45, 48-49), more sclerotized laterally at the point where they connect to a thin, broad and translucent septum (Fig 44-45, 48-49); spermathecae narrow and upwardly directed, arranged at the posterior end of the epigyne; left fertilization duct deformed (Figs 44-45, 48-49).

Acknowledgements. We are grateful to Rev. Fr. Prasanth Palackappillil CMI, Principal, Sacred Heart College, Thevara, Cochin, for providing us with access to their research facilities. We are indebted to Dr Dmitri Logunov (Manchester, UK) for providing valuable suggestions and editing the $\mathrm{ms}$. We are also grateful to two anonymous referees for their valuable comments on the ms. We also wish to thank $\mathrm{Mr}$ Jimmy Paul, Sacred Heart College, Thevara, Cochin, for providing beautiful photographs of live specimens. We wish to acknowledge the Ministry of Environment, Forest \& Climate Change (MoEFCC), New Delhi, for financial support under All India Co-ordinated Project on Capacity Building in Taxonomy: No. 22018/04/2010-CS (AICOPTAX).

\section{References}

Benjamin S.P. 2004. Taxonomic revision and phylogenetic hypothesis for the jumping spider subfamily Ballinae (Araneae, Salticidae) // Zoological Journal of the Linnean Society. Vol.142. P.1-82.

Benjamin S.P. 2006. The male of Marengo nitida with the description of $M$. rattotensis new species from Sri Lanka (Araneae: Salticidae) // Zootaxa. Vol.1326. P.25-36.

Maddison W.P. 2015. A phylogenetic classification of jumping spiders (Araneae: Salticidae) // Journal of Arachnology. Vol.43. P.231-292. http://dx.doi.org/10.1636/arac-43-03-231-292.

WSC 2019 World Spider Catalog (version 20.0). Natural History Museum Bern; online at: http://wsc.nmbe.ch, accessed on (accessed on 29 December 2018). doi: 10.24436/2

Responsible editor D.V. Logunov 